\title{
Стилијан Чилингиров и његов допринос очувању српских библиотека које су Бугари запленили у Првом светском рату
}

\author{
Елизабета Георгиев \\ Народна библиотека „Детко Петров”, Димитровград \\ betageorgiev@yahoo.com
}

\begin{abstract}
Сажетак
Стилијан Чилингиров је културни делатник Бугарске из прве половине 20. века који је својим радом оставио значајан траг у бугарској култури и умногоме допринео развоју бугарских читалишта и библиотека. Бавио се књижевним и научним радом, теоријом и историјом књижевности, књижевном критиком и историјом. Овај рад доноси до сада мало познате податке о улози Стилијана Чилингирова у очувању српских књига заплењених у Првом светском рату, међу којима су биле и књиге из Народне библиотеке Србије. Урађен је на основу истраживања архивске грађе из Централног државног архива, Народне библиотеке „Ћирило и Методије” у Софији и мемоара самог Чилингирова, те података презентованих у различитим публикацијама везаним за историју бугарске националне библиотеке. О судбини заплењених српских књига у Великом рату, о којима је до 1919. године бринула Народна библиотека у Софији, релативно мало се зна из постојећих историјских извора, па је представљање до сада непознатих података из бугарских извора од значаја за историју српског библиотекарства.
\end{abstract}

Кључне речи: Стилијан Чилингиров, Први светски рат, збирке српских библиотека, ратни плен, Народна библиотека Србије, Народна библиотека у Софији (Бугарска), Јован Томић

\section{Увод}

Бугарску културну сцену на почетку 20. века карактеришу изражени напори образоване елите за формирањем институција које ће неговати и развијати бугарску културу. Образовање, наука, читалишта, развој библиотекарства и музеологије, позоришне и ликовне уметности, архитектура, музика и књижевност постали су значајан фактор у развоју културног и етничког идентитета и националног осећања Бугара. Дугогодишња турска владавина успела је да маргинализује културу народа, који је током периода препорода, подстичући формирање читалишта и школа, успео да брзо после ослобођења (1878. године) успостави квалитетан културни живот у новој држави.

Изражени патриотизам образованих појединаца и жеља за што бржим културним развојем допринели су формирању важних институција културе од којих је у ослобођеној Бугарској најстарија Национална библитека. По идеји учитеља из Софије Михајла К. Буботинова, 10. децембра 1878. године формирана је комисија са председником Марином Дриновим, ${ }^{1}$ која је имала циљ да створи бугарску националну библиотеку. Она је званично основана 17. јуна

\footnotetext{
1 Марин Дринов (1838-1906), председник комисије, бугарски историчар и филолог, који је свој радни век углавном провео у Русији. Он је један од родоначелника бугарске историографије и један од оснивача Бугарског књижевног друштва, данас Бугарске академије наука.
} 
1879. године као државна институција са називом Бугарска народна библиотека (Българска народна библиотека). ${ }^{2}$

Једна од најзначајнијих личности у историји бугарског библиотекарства јесте Стилијан Чилингиров, руководилац Народне библиотеке и историчар развоја читалишта у Бугарској. Писац, етнограф, историчар, истакнута јавна личност, доживео је судбину више критикованог него цењеног интелектуалца, посебно у периоду после Другог светског рата. Занемариван у Бугарској дужи низ година, пре свега као писац, тек деведесетих година прошлог века културна заједница се упознала са његовим активностима и стваралаштвом. Иако у својим историјским студијама које се односе на Србију показује неблагонаклон однос према овој земљи и њеном народу, не могу да се игноришу чињенице да Чилингиров има значајне везе са Србијом, које га чине добрим познаваоцем пре свега српске културе и књижевности.

Посебно важна за истраживаче је архива Стилијана Чилингирова ${ }^{3}$ која се налази у Централном државном архиву у Софији. ${ }^{4}$ У њој се могу пронаћи многи подаци о његовим односима са Србијом, од првог одласка у Београд, још као студента 1904. године, до његове активне улоге у културном животу градова поред границе (Пирот, Цариброд), током и после Првог светског рата. Из архиве се може видети да, и поред критичког става према Србији и Србима, Чилингиров поштује српску књижевност и српску књигу и заинтересован је за српске ауторе. Од посебног значаја за историју српског библиотекарства је његова књига Буїарска ии-

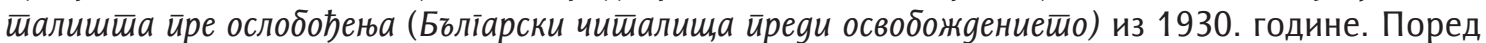
прегледа и података о развоју бугарских читалишта пре бугарског препорода, као наставка културних токова у Европи оног времена, у књизи се налазе и подаци о четири српска читалишта - у Нишу, Пироту, Димитровграду (Цариброду) и Врању.

Свакако најзначајнију улогу у вези са српском књигом Чилингиров је одиграо као кључна личност у очувању и сређивању заплењених српских књига у Првом светском рату, које су као ратни трофеј достављене Народној библиотеци у Софији. Он је 1915. и 1916. године био члан главне комисије задужене за пријем српских публикација, а касније један од главних стручњака чија дужност је била њихово сређивање и инвентарисање. По завршетку Првог светског рата, Стилијан Чилингиров је, као директор Бугарске народне библиотеке и особа најупућенија у судбину српских књига, био одговоран за њихову примопредају комисији сачињеној од представника Народне библиотеке Србије и француских војних снага, које су спроводиле ове активности.

Поред представљања лика и дела Стилијана Чилингирова, овај рад се првенствено бави мало познатим подацима о судбини заплењених српских књига у Нишу и другим градовима 1915. и 1916. године и улози Чилингирова на њиховом очувању и сређивању после приспећа у Софију. Истражена је грађа Бугарског историјског архива при Народној библиотеци „Св. Кирило и Методије" у Софији, грађа из архива Чилингирова која се налази у Централном државном архиву и у Меморијалном кабинету Чилингирова при Националном музеју књижевности.

По први пут се објављују подаци из бугарских извора о путу и судбини заплењених српских књига у Великом рату, о напорима и залагању бугарске националне библиотеке и самог Чилингирова да их сачувају, о односу библиотечке и културне јавности Бугарске тога доба према такозваном „ратном трофеју".

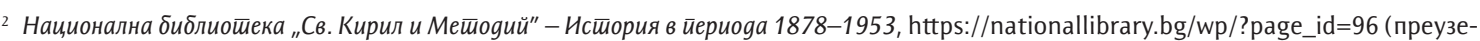
то 12. 1. 2017).

3 Фонд Стилиян Чилингиров, ЦДА София, Фонд 108к, опис 2.

${ }^{4}$ У даљем тексту ЦДА.
} 


\section{Стилијан Чилингиров - живот и дело}

Не постоји бугарски културни радник који као Стилијан Чилингиров ${ }^{5}$ тако аутентично, у детаље и са невероватним осећајем за историчност документује утиске о савременицима и догађајима којима је био сведок. Кроз преписку, текстове у периодици, кроз сачуваних десетак свезака и неколико стотина страница дневника и скоро исто толико страница мемоара, Чилингиров осликава друштвени и културни живот Бугарске свога времена. За већину историчара прве половине 20. века, првенствено културног живота Бугарске, незаобилазни извори информација су управо богата архивска грађа, дневници и мемоари Чилингирова. ${ }^{6}$

После 9. септембра 1944. године ${ }^{7}$ Чилингиров је због својих политичких ставова и јавних иступања пао у заборав. Његово стваралаштво је проглашено осредњим и без значајних књижевних остварења. Као последица тих оцена, Чилингировљева дела су уклоњена из наставног плана и програма.

Први „Списак фашистичке литературе која подлеже одузимању по XII одредби Већа министара од 6. октобра 1944." укључује два дела Чилингирова - Поморавље на основу срйских свеgочена (Поморавия йо срббски свияешелсиева, 2. изд., Скопие, 1942) и Кроз Макеgонију (През Макеgония, 1942). На основу Наредбе број 48 Савета министара 15. фебруара 1952. године још две његове књиге су забрањене - Шйа је Буїарин gао gруїим нароgима (Какво е gал бблїаринъте на gруїите нароgи, 1941) и Срби и ми (Сәрбите и ние, 1930) - ове књиге доспевају на „I списак фашистиче и декадентне, религиозне, опортунистичке, реакционарне и безвредне литературе", тако што се у наредби прецизира да одузимању подлежу књиге издате у периоду 1923-1944. и 1944-1951.8

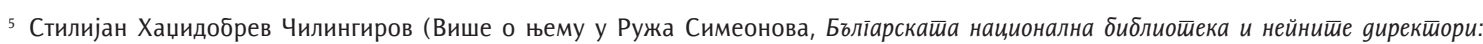
1879-2009 (София: Издателска къща „Христо Ботев”, 2009), 91), у бугарској култури познат и као последњи представник препорода (иослеgния вбзрожgенеи) рођен је 26. октобра 1881. године у граду Шумену у породици занатлије. У родном граду завршио је педагошку школу, паралелно радећи као обућарски и књижарски калфа, чак и као чобанин. На железничкој станици у Пловдиву 1897. године учио је за телеграфисту. Једно време радио је и као учитељ у селима у околини Варне. Године 1904 . уписује педагогију на универзитету у Софији, тада Вишој школи, да би 1909. завршио филозофију и педагогију на Софијском универзитету. Пошто је био добар студент, тадашњи министар просвете Бугарске Иван Шишманов га шаље у Немачку, где је специјализирао естетику и књижевну историју у Берлину и Лајпцигу (1905-1907). Чилнгиров је био активан у часописима Звезgииа и Школски ирреілеg (Уиилищен йреїлеg). Радио је као професор немачког и бугарског језика у Другој софијској мушкој гимназији. Даљи професионални пут га води у Народну библиотеку у Софији, где у то време раде велики бугарски писци П. П. Славејков (Пенчо Петков Славејков; 1866-1921, бугарски песник и културни радник; у Народној библиотеци у Софији на месту заменика, а касније директора 1901-1911) и П. К. Јаворов (Пејо Јаворов; 1878-1914, бугарски песник, један од зачетника бугарске модерне; значајан део свог кратког живота провео је у Народној библиотеци у Софији). Од 1911. је уредник новина Буїарска (Бблїария), а у периоду од 1914-1915. заједно са Д. Мишевим уређује часопис Бразgа. Био је секретар Напредно-либералне партије, коју напушта 1913. године. Током Балканских ратова Чилингиров је био дописник штаба Друге бугарске армије. Јавно се изјашњавао против Савезничког рата и уласка Бугарске у Први светски рат. Био је члан Поморавског научног комитета (Бугарска научна организација створена 1917. године, чији је основни задатак био оживљавање бугарског националног идентитета међу житељима Поморавља и Тимока. Комитет је створен када је већи део Поморавља и Тимока био под контролом Царства Бугарске. На то место изабрале су га поморавска и тимочка емиграција у Бугарској. У комитет су укључени научници и истакнути чланови јавности. Његов основни принцип је Без насиља, без иринуgе! Састанци комитета су се одржавали углавном у Нишу, главном граду Моравске области, где су се доносиле најважније одлуке од локалног значаја, углавном из области културе и образовања. Изузетну подршку његовим активностима пружао је Петар Дарвингов - начелник штаба Моравске области, војне инспекције, са центром у Нишу. Војне власти су омогућиле комитету да организује наступе и спроводи културне и образовне активности на страницама листа Моравски ілас штампаног у Нишу и дистрибуираног у Моравској војно-инспекцијској области. Председник Поморавског научног комитета био је академик Сава Живков Дацов (рођен у Зајечару), а чланови су били: Спас Вацов, Краста Крастев, Петар Зубов, Елисеј Манов (сви родом из Пирота), Стилиан Чилингиров, Анастас Иширков и Гаврил Занетов. После Првог светског рата и враћања Поморавља Србији створен је Западнопокрајнски научни институт (Западнопокрайненският научен институт)). У периоду од 1916. до 1919. Чилингиров је био заменик директора Народне библиотеке у Софији, директор Библиотеке у периоду од 1919. до 1922, а 1923. године постављен је за директора Народног етнографског музеја. Један је од оснивача Савеза бугарских писаца и његов председник 1941-1944, а у истом периоду и председник Врховног читалишног савеза. Умро је 22. новембра 1962. године у Софији.

6 Фонд Стилиян Чилингиров, ЦДА София, Фонд 108к, опис 2.

7 Насилна промена власти у Бугарској, десила се у ноћи између 8. и 9. септембра 1944. године. Тада је збачена влада Константина Муравиева и на власт је дошао Отаџбински фронт на челу са Кимоном Георгиевим. Преузео је власт уз помоћ Трећег украјинског фронта Црвене армије. После овог пуча дешавају се велике политичке, економске и друштвене промене у бугарском друштву. Бугарска пада у совјетску сферу утицаја.

8 Румен Леонидов, Премблианите gневници на Сйилиян Чилинїиров, https://kibea.net/press/2024 (преузето 12. 1. 2017).
} 
Удружење писаца Бугарске смењује Чилингирова са места председника, а од његовог деловања се оградио и Читалишни савез.

Имајући у виду плодотворност и разноврсност стваралаштва овог аутора, после његове смрти поставило се питање огромног књижевног наслеђа и судбине куће. Комисија одељења „Културе и уметности" 9 је утврдила да су заоставштина писца, кабинет, књиге и друго својеврсни споменик који може да послужи за изградњу Музеја књижевности, те је предложено да се његова архива у потпуности сачува.

Ипак до тога није дошло, јер је на месту Чилингировљеве куће, која је 1968. године проглашена спомеником културе, подигнута стамбена зграда. Тек 1985. године група стручњака из Националног музеја књижевности обновила је кабинет великог културног радника и писца у коме се чува његова лична библиотека. Подаци говоре да је библиотека имала негде око 36.000 јединица, а да је сачувано $21.000^{10}$ монографских и периодичних публикација. ${ }^{11}$

Значајан део личне библиотеке писца чини белетристика на српском језику, као и књиге српских и страних аутора посвећене историјској прошлости Срба. Преко 200 издања Српске књижевне задруге Чилингиров је добио као поклон и захвалност Народне библиотеке у Београду у знак признања због помоћи да се спасе књижни фонд ове библиотеке током Првог светског рата.

Међу књигама на српском, у Меморијалном кабинету Чилингирова, налази се и неколико са печатима српских библиотека, пре свега библиотеке у Пироту. Реч је о књигама које се баве српском историјом, па будући да се сам Чилингиров интересовао за ову тему и писао о томе, вероватно је за потребе свог научног рада „позајмио” те књиге из гомиле заплењених књига, које су достављене библиотеци у Софији.

Чилингиров је писао приповетке, романе, есеје, путописе, драме, поезију, за децу и одрасле, мемоаре, радове из уметности, политике, књижевности, педагогије и друго. Аутор је скоро 100 наслова објављених као засебне публикације и преко 1500 чланака у зборницима и штампи, одржао је више од 800 предавања. Прве своје радове штампао је у часопису Звезgииа 1898. године. Свој књижевни рад ${ }^{12}$ Чилингиров доживљава као просветитељску и културну обавезу, која има задатак да бугарску књижевност доведе на ниво европских тенденција тога доба. Велики број његових дела, посебно романи, имају аутобиографску основу коју аутор вешто надограђује, имплементирајући актуелни друштвени, културни и политички тренутак, па се тако у њима често тражи решење за друштвене и националне проблеме. Чилингиров је писао и под псеудонимима: Булгарикус, Батју Стилју, Дејан Скромниј, С. Добрев, Један Бугарин (Един българин), Скитач, Прогресист, С. Спартански, Стиљу Чирака и другим. Преводио је поезију Хајнеа и Петефија, а његово стваралштво је превођено на италијански и српскохрватски језик.

Од посебног значаја је научноистраживачки рад Стилијана Чилингирова који обухвата студије, монографије из бугарске историје, етнографије, фолклора, педагогије, али и историјска

\footnotetext{
9 Мемориален кабинеше Сишилиян Чилиніиров, http://nlmuseum.bg/index.php/filiali/memorialen-kabinet-stiliyan-chilingirov (преузето 13. 1. 2017).

${ }^{10}$ Сшилиян Хаgжияобрев Чилиніиров, http://archive.li/cXF8w (преузето 13. 1. 2017).

${ }^{11}$ Интересантан је податак да међу сачуваним књигама има много оних са посветама скоро свих познатих бугарских писаца који су живели и радили крајем 19. и у првој половини 20. века. Међу тим књигама је и збирка од скоро 300 инкунабула и старих и ретких књига изузетне вредности из периода са краја 18. века до ослобођења Бугарске 1878. године. Ово су публикације на бугарском, руском, српском, грчком, немачком и француском језику. Међу њима су библиографски уникати као Оїлеgало Кирила Пејчиновића из 1816. године, Рибен буквар (Рибљи буквар) Петра Берона из 1824 године, издања Неgелник Софронија Врачанског и још много тога. У спомен-соби се налази и део личне архиве писца као и слике познатих бугарских сликара Петра Морозова, Хараламбија Тачева, Преслава Каршовског и многих других.

12 Главни ликови у књижевности Чилингирова су сељаци, занатлије, учитељи. Он их вешто користи како би на најбољи начин осликао друштвени амбијент Бугарске у тешким временима после турског ропства. Тако је роман Хлеб наш насушни апотеоза бугарског еснафства. У овој књизи он представља борбу за црквену и политичку независност Бугара у време бугарског препорода, а после Ослобођења слику тешког прихватања модерне индустријализације. Чилингиров је и аутор романа Влаgо Булайов који је први покушај стварања сонетског романа у бугарској књижевности.
} 
истраживања бугарског читалишта и библиотечке делатности. Аутор је хрестоматија и читанки за основну школу. Интересантан је податак да је Чилингиров припремио, али није успео да изда, библиографију бугарске периодике од 1844. до 1910. године која броји око 200.000 библиографских јединица.

У својим публицистичким радовима Чилингиров велику пажњу посвећује друштвеном и културном тренутку. Интригантна су његова запажања о пријатељствима са књижевницима, о друштвеним сукобима и препиркама међу писцима, успесима и неуспесима књига и аутора. Чилингиров не штеди оцене о томе шта се дешавало у друштву. И што је најважније, циљ му је објективан опис догађаја, ставља их у контекст укупног интелектуалног живота, не улепшава чињенице. Ове карактеристике чине његове публицистичке радове поузданим изворима информација о бугарској културној историји током прве четири деценије 20. века, која је још увек само делимично документована.

\section{Рад Стилијана Чилингирова у Народној библиотеци у Софији}

Стилијан Чилингиров у Народној библиотеци у Софији почиње да ради 1914. године као учитељ који је ту послат службено. Ружа Симеонова у књизи о историји ове библиотеке наглашава да „постоји симболика у чињеници да Чилингиров заузима место обећавајућег и вредног научника др Ивана Димитрова који је погинуо у рату". ${ }^{13}$ Будући да наставља пут првог школованог библиотекара Ивана Димитрова, Чилингиров брзо улази у суштину библиотекарства, проналазећи се у овој новој науци. Његови биографи често истичу да се као библиотекар почетник у националној библиотеци првенствено интересовао за књижевност. Као члан управе Библиотеке Чилингиров ради и сарађује са др Н. Бобчевим, ${ }^{14}$ др Ал. Златановим ${ }^{15}$ и др М. Тиховим, ${ }^{16}$ великим бугарским интелектуалцима тога доба.

По одласку М. Тихова 1916. године са места директора Националне библиотеке, Чилингиров, сам руководи и велики део стручног посла ради у Библиотеци сам, будући да је мушки део колектива био на фронту. ${ }^{17}$

Од самог почетка деловања у Библиотеци, Чилингиров је посебно интересовање показивао за старе и ретке књиге, али и за вредну периодику и архивску грађу из доба бугарског препорода. Године које је провео на месту руководиоца библиотеке, иако тешке, ратне и са много проблема, у историји бугарског библиотекарства и у историји бугарске националне библиотеке забележене су као године у којима је добила неколико веома важних и значајних издања. ${ }^{18}$ Тако је 1917. године Библиотеци лично цар Фердинанд поклонио оргинални примерак дела Марва Орбина из 1601. године. Године 1918, на иницијативу опуномоћеног амбасадора Бугарске у Русији Ст. Чапрашикова, Библиотека набавља велики број новина, фотографија и часописа који се односе на политичке и друштвене промене изазване Октобарском револуцијом и периодом пре ње. Тих година библиотечки фонд је обогаћен бројном архивском грађом у вези са бугарским препородом, као и личним архивама познатих писаца и револуционара.

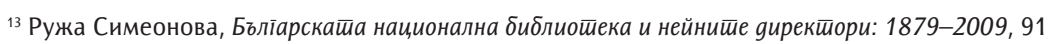

${ }^{14}$ Никола Савов Бобчев је бугарски фолклориста, књижевни критичар и преводилац са руског језика. Од 1902. редовни члан Бугарског књижевног друштва, данас Бугарске академије наука, Бобчев је један од малобројних бугарских ученика немачког психолога Вилхелма Вундта.

${ }^{15}$ Александар Златанов директор Народне библиотеке у Софији у периоду од 1913. до 1915. године.

${ }^{16}$ Михаил Тихов директор Народне библиотеке у Софији у периоду од 1915. до 1916. године.

${ }^{17}$ Године 1917. у Софији се догодио веома јак земљотрес у коме је видно била оштећена зграда библиотеке, али и зграда Славјанског добротворног друштва, у којој су биле смештене заплењене српске књиге. Као добар руководилац који се брижно односио према повереном му друштвеном добру, Чилингиров је алармирао све органе власти о стању установе важне за државу, те је омогућио да улицом на коју излази библиотека не пролазе тешка возила како не би додатно повећавала постојећа оштећења.

${ }^{18}$ Ружа Симеонова, Нав. дело, 93.
} 
Поред значајних обавеза и задужења које је преузео на себе у очувању бугарског писаног културног наслеђа, Чилингиров је у периоду Првог светског рата велику пажњу посветио истраживању и очувању бугарских културних и историјских споменика првенствено на територији Добруџе, где је службено боравио и истраживао материјално и нематеријално културно наслеђе, а значајно је његово посредовање у војном представништву у Букурешту у вези са слањем стручњака који ће проучавати живот и културу бесарабијских Бугара. ${ }^{19}$

За директора Народне библиотеке Чилингиров је званично постављен 1. новембра 1919. године. Ослањајући се на своја размишљања и тежње да уздигне значај Народне библиотеке, по завршетку Првог светског рата Чилингиров прослеђује Министарству просвете пројекат за промену Закона о народној просвети и Закона о депозиту књига, који је претходно усагласио са мишљењем библиотечког комитета. По њему „контрола књижног депозита треба буде изузета из општег административног надзора владе, тако што ће остати једино у прерогативима Министарства просвете".$^{20}$ У извештају који прати овај предлог, Чилингиров инсистира да се коначно дефинише место Народне библиотеке у бугарском друштву.

Као директор, Чилингиров наставља библиотечку политику П. Славејкова да Народна библиотека не треба да врши улогу великог читалишта. Инсистира да се поред већ постојећег одељења старе и ретке књиге при Библиотеци отвори и Архивско одељење, тако што ће Архив бугарског препорода који се до тада налазио у Етнографском музеју у Софији бити пренет у Народну библиотеку. Управо због те упорности и труда у очувању архивске грађе, рукописне и старе књиге, многи теоретичари бугарског библиотекарства улогу Чилингирова истичу као значајну и пресудну за чињеницу да се данас Бугарска национална библиотека може поносити богатством овог материјала.

Резултат упорног и континуираног рада и инсистирања Чилингирова да се Народној библиотеци да значајније место у бугарском друштву видљиви су већ 1920. године, када је буџет библиотеке са 15.000 лева повећан на 150.000. ${ }^{21}$ Поред тога, Чилингиров на различите начине, користећи свој углед и упорност, у библиотеку доводи значајне бугарске интелектуалце, писце, али и образоване руске емигранте који ће у наредном периоду значајно допринети њеном развоју. Све време инсистира и на сређивању фонда, па до 1921. Народна библиотека има азбучни и предметни каталог израђен по стандарима тадашње библиотечке науке.

Као директор, непрекидно и без задршке води упорну борбу са влашћу за обезбеђивање простора и одговарајуће зграде за библиотеку, односно да се њена зграда у потпуности реконструише и адаптира. Не наилази на одобрење Министарства ни других органа управе, па сукоби међу њима постају све израженији.

Почетак краја директоровања Чилингирова у Народној библиотеци је 29. мај 1922. године, ${ }^{22}$ када у зграду Библиотеке, у време његовог одсуства, упада група резервних официра који су се враћали са митинга у центру престонице. Вођа митинга, генерал Лазаров, са балкона зграде одржао је говор против управе Бугарског земљорадничког народног савеза. После овог догађаја министар Народне просвете Ст. Омарчевски наређује да се изврши истрага и да се службеници који су дозволили улазак војника у Библиотеку казне. Министар инсистира да Чилингиров именује и проследи кривце, али он то игнорише. Његово објашњење је било да ниједан службеник не може да се успротиви војницима, а не постоји начин да се замене радници ако им да отказ. Такав однос и непокорност према министарству разлог је што је Чилингиров неколико месеци касније добио отказ и што је пребачен на посао у Етнографски музеј у Софији.

\footnotetext{
${ }^{19}$ Исто, 92

${ }^{20}$ Исто, 93.

${ }^{21}$ Исто, 94.

22 Исто, 94
} 


\section{Допринос Стилијана Чилингирова очувању српских књига заплењених у Првом светском рату}

У историји српских библиотека име Стилијана Чилингирова је у вези са његовом улогом и доприносом у спасавању заплењених књига Народне библиотеке у Београду, те библиотека у Нишу, Пироту и другим градовима Источне Србије током Првог светског рата. Једна од многих недаћа које је овај рат донео српском народу је и заплена књига из националне и других библиотека које су своју неизвесну судбину наставиле у Софији.

Народна библиотека у Београду функционисала је до почетка Првог светског рата. За време бомбардовања Београда 1915. године део фонда је у циљу спасавања пребачен у Народну библиотеку у Нишу и у друге зграде. ${ }^{23}$ Мираш Кићовић у књизи Нсйорија Нароgне библиошеке у Беоіраgу наводи речи Анастаса Мајзнера упућене Светозару Матићу, којим га овај упознаје са разлозима пресељења Народне библиотеке. „Због пожарничке осматрачнице на крову зграде у којој је била Библиотека и због инсталације бежичне телеграфије на згради Класне лутрије у близини Библиотеке, непријатељ је из тешких топова бомбардовао и јако оштетио једно одељење Библиотеке у њеној згради и њен магацин књига у суседном Народном музеју (садашњем Природно-математичком факултету). 3бог тога је велики део Библиотеке евакуисан у Ниш (рукописи, инкунабуле, новине, часописи), одакле су 1915. рукописи послати у Косовску Митровицу, а остало су Бугари однели у Софију". ${ }^{24}$

Евакуацију Библиотеке из Београда извршили су др Михаило Поповић, помоћник и Анастасије Мајзнер, руководилац.

Децембра 1915. године бугарске снаге улазе у Ниш и у такозваној „Зеленој гимназији” („Зелена гимназия"), у оштећеном конаку, војници налазе књиге и рукописе из Народне библиотеке Србије, као и збирке минерала, медицинске инструменте, различите уметнине и предмете ${ }^{25}$ који су као ратни трофеји пребачени у Софију. Било је око 70.000 књига упакованих у 209 сандука и натоварених у 5 вагона. ${ }^{26}$

Велико Јорданов у књизи о историји Народне библиотеке у Софији наводи интересантан податак да је, приликом уласка бугарске војске у Србију, Народна библиотека предузела поступке код војних и грађанских власти да сачувају од уништења и да прикупе све књиге и друге културне творевине које нађу на терену, те да их пошаљу у ову институцију на чување. „Посредовање библиотеке, као што је и требало очекивати је било не само уважено, већ и радо прихваћено. У граду Нишу су децембра 1915. године нађене у сандуцима у оштећеном конаку књиге из библиотека из Београда и других српских градова. Приликом повлачења из Ниша, српска војска није успела да их понесе. Тако су књиге из те и других библиотека биле пренесене у Народну библиотеку у Софију". ${ }^{27}$

Тадашњи директор бугарске националне библиотеке М. Тихов послат је у Ниш како би пратио паковање и утовар вредних збирки. По доласку књига у Софију министар народне просвете Бугарске П. Пешев 23. јануара 1916. године именовао је комисију у саставу: директор Народног археолошког музеја др Б. Филов, директор Народне библиотеке М. Тихов, библиотекар

\footnotetext{
${ }^{23}$ Александра Вранеш, Нишка нароgна библиоешека: докуменш и свакоgневица (Ниш: Народна библиотека „Стеван Сремац", 2004), 56.

${ }^{24}$ Мираш Кићовић, Нсш̄орија Народне библиошеке у Беоіраяу (Београд: Народна библиотека, 1960), 137.

25 У богатој архивској грађи из Бугарског историјског архива при Народној библиотеци „Св. Кирило и Методије” која презентује пут и боравак српских књига у Софији, мешају се појмови Универзитетска и Народна библиотека. Будући да се у многим дописима, записницима и другим материјалима наводи да се међу заплењеним књигама, новинама и архивама налазе и колекције минерала, лабораторијски и медицински инструменти, медикаменти, уметнички предмети, може се закључити да је у Ниш, осим књига, достављена и покретна имовина неких београдских факултета, па стога Бугари у првим дописима и писмима наводе да су у конаку Зелене гимназије у Нишу нашли Београдску универзитетску библиотеку.

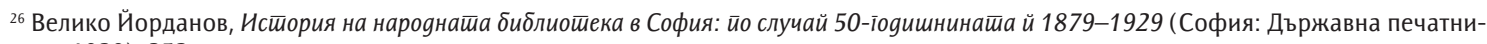
ца, 1930), 253.

${ }^{27}$ Исто.
} 
при универзитетској библиотеци С. Аргиров, финансијски инспектор Г. Сотиров и Стилијан Чилингиров као главни библиотекар при Народној библиотеци ${ }^{28}$ која је добила задатак да прими, опише и среди српске књиге. Најважнији задатак је извршио библиотекар Стилијан Чилингиров заједно са 10-20 службеника. 3бог чињенице да је скоро цео мушки персонал Библиотеке био на фронту, Чилингиров је био приморан да за потребе премештаја и сређивања српских књига унајмљује раднике, које у извештајима и рапортима, те списковима за награду за рад, назива надничарима. Успео је и да обезбеди смештај за такозвани „ратни трофеј” у 7 соба Словенског добротворног друштва које се налазило преко пута библиотеке. Очување збирки српских библиотека прихвата не само као личну мисију, него и као част за националну културу. Сређене српске књиге, по његовим речима, проучавали су бугарски научници, песници, публицисти, чији резултат је неколико публикација о Македонији, Поморављу и Тракији и много научних и публицистичких текстова. ${ }^{29}$

Изузетно велика и богата архивска грађа у оквиру фонда 35 (архивска јединица 593 лист 1-911) која се налази у Бугарском историјском архиву у Народној библиотеци „Свети Кирило и Методије", детаљно говори о путу српских књига из Ниша у Софију, о проблемима њиховог смештаја и великим напорима управе библиотеке, првенствено Стилијана Чилингирова, да се оне сачувају и неоштећене врате установама и појединцима којима су припадале.

По завршетку Првог светског рата поставља се питање судбине српских књига у Софији. Чилингиров у извештају Министарству народне просвете ${ }^{30}$ истиче да српске књиге никада нису биле сматране делом богатства Народне библиотеке Бугарске, будући да су скупљене с циљем да не буду уништене од суровости рата. Он предлаже Министарству да буду предате српској држави која се обнавља. „Да чувамо туђе богатство и да за њега стварамо трошкове је непотребно". Ипак, за активности смештаја и сређивања српских књига тражени су специјални кредити који су достигли до 29.128,05 лева за наднице ангажованог персонала и 17.285,67 лева за кирију, осветљење, грејање и друго -укупно 55.238,62 лева. ${ }^{31}$

„Српско књишко богатство о коме је реч посебно је сређивао наш персонал и докле год се чувало код нас постојало је под називом 'Српска библиотека'. То најбоље показује да се на њега није гледало као на трофеј, већ као на збирку, намењену да се уредно преда њеном власнику. Као збирка ова библиотека фигурира и у буџету где су у ставу 33 предвиђене суме неопходне за њено одржавање. Да се на ово богатство није гледало тако, није било потребе да се чува одвојено са посебно одређеним средствима, будући да је лако могло да се смести са нашим, да се суме планирају у општем буџету поверене ми Народне библиотеке", 32 пише Чилингиров даље у свом извештају Министарству.

Почетком 1919. године, по налогу министра просвете Краљевине СХС Љубомира Давидовића, у Народну библиотеку у Софији долазе Јован Томић, Јован Ердељановић, Пера Поповић и Анастас Мајзнер, као чланови комисије која је имала задатак да „поради на враћању свих српских библиотека из софијске Народне библиотеке". ${ }^{33}$ У опису враћене колекције укључено је 36.604 повезаних томова, 31.425 неповезаних и 377 фасцикли са новинама. Књиге су послате у Београд у 146 сандука. „По причању J. Томића Бугари су задржали књиге које су говориле о Македонији и Старој Србији, иначе су цео фонд Народне библиотеке држали груписано, а одвојено само Мињеову Паширолоїију, али су и њу вратили". ${ }^{34}$

\footnotetext{
${ }^{28}$ БИА, Ф. 35, архивска јединица 593, лист 35.

${ }^{29}$ Велико Йорданов, Нав. дело, 254.

${ }^{30}$ Исто, 253.

31 Исто, 253.

32 Исто, 254.

${ }_{33}$ Бранка Драгосавац, Јавне библиошеке у Србији og 1901. go 1918. (Панчево: Градска библиотека; Ниш: Народна библиотка „Стеван Сремац"; Неготин: Народна библиотека „Доситеј Новаковић", 2016), 122.

${ }^{34}$ Мираш Кићовић, Нсшорија Нароgне библиошеке у Беоїраgу, 138.
} 
Већина историчара бугарских библиотека спасавање заплењених српских библиотека Стилијана Чилингирова дефинише као једну од његових заслуга за очување европског културног наслеђа. „Захваљујући далековидости и уједињеним напорима Тодора Александрова ${ }^{35}$ и Стилијана Чилингирова сачуване су од уништавања збирке српских библиотека. Тако је као резултат тога Бугарска ослобођена плаћања преко 10.000 .000 лева, суме коју је српска влада намеравала да тражи као компензацију од Бугарске за књиге које су сматране уништеним". ${ }^{36}$

Да је Србија знала да оцени залагање Чилингирова, потврђује и орден Белог орла V степена ${ }^{37}$ који се чува у његовом меморијалном кабинету, а који је добио за спасавање од уништења 70.000 књига Народне библиотеке Србије током Првог светског рата.

У тексту „Како су спасене књиге српске народне библиотеке (успомене)” („Как бяха спасени книгите на сръбската народна библиотека (спомен)") Стилијан Чилингиров подробно пише о својим успоменама у вези са тим догађајем. Његово ангажовање на прикупљању књига са српских територија које су Бугари окупирали 1915. почиње 23. октобра исте године, када га Министарство народне просвете шаље у Пирот да прикупи библиотеке „друштвене и без власника, приватне, које се налазе у граду Пироту, како би биле сачуване, имајући у виду да културне вредности током рата често бивају уништене". ${ }^{38}$ У Пирот одлази 28. октобра, 13 дана пошто га је заузела бугарска војска. Чилингиров истиче да му је у овом послу главни задатак био да бугарским војним и грађанским властима објасни своју мисију и да тражи од њих сарадњу, коју је на крају и добио. Пописао је пиротске библиотеке, о чему сведочи и извештај достављен Министарству народне просвете. ${ }^{39}$

„После извесног времена добио сам нови задатак. Овога пута у Ниш је упућен мој помоћник Михаил Тихов са задатком да тамо покупи српску универзитетску библиотеку, која је истовремено играла улогу и народне. Када је и он испунио свој задатак и донео много сандука са књигама, а међу њима и једну скулптуру далматинског скулптора Мештровића, фигуру из пројектованог храма на Косову, латио сам се посла да ређам оно што смо обојица донели, српско књижно богатство". 40

У даљем тексту Чилингиров истиче да је специјално за то био изнајмљен простор Словенског добротворног друштва (Славянско благотворително дружество), углавном доњи спрат, који се састојао од једног великог, дугачког салона и неколико соба. Салон је био испуњен низом високих полица, које су достизале чак до тавана и биле поређане паралелно целом дужином просторије.

У циљу сређивања српских књига и за проучавање српске збирке периодике Чилингиров је замолио да му са фронта пошаљу неколико гимназијских учитеља, јер је особље које је имао на платном списку било недовољно. С фронта су му послали Христа Герчева, гимназијског учитеља из Шумена, Сашу Ајанова из Бургаса и Михаила Димитрова, који су се, по Чилингировљевим речима, ревносно латили посла: ређали су књиге и проучавали су новине.

„Управо када смо поређали књиге које су испуниле не само салон већ и друге собе, попуњене полицама и када смо се латили да упоређујемо библиотечко богатство са листићима из каталога који су довучени у нереду у једном грубом храстовом сандуку, десио се преокрет у рату. Бугари су морали да се суоче са чињеницом да су побеђени и да затраже мир. У Софији је смештен штаб француске војске. Мени ништа друго није преостало сем да замолим Министарство народне просвете да оно саопшти тамо где треба, да им је српска библиотека на располагању, само да ми јаве коме и када треба да је предам". ${ }^{41}$

\footnotetext{
35 Тодор Александров (1881-1924), бугарски револуционар, члан ЦК ВМРО, учесник у ратовима за национални уједињење.

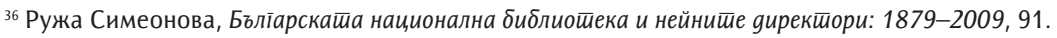

${ }^{37}$ Да наязбрнем в стиаяйа на Вазов и в кабинешиа на Пейо Яворов, http://www.desant.net/show-news/37239 (преузето 18. 1. 2017).

${ }^{38}$ Стилиян Чилингиров, „Как бяха спасени книгите на Сръбската народна библиотека: (Спомен)”, Библиоеиекар 11 (1958): 64.

${ }^{39}$ Протокол Стилиян Чилингиров, ЦДА Софија, Фонд 108К, опис 2, архивска јединица 2409.

${ }^{40}$ Стилијан Чилингиров, Нав. дело: 65.

${ }^{41}$ Исто: 66.
} 
Чилингиров у тексту детаљно описује сам сусрет са делегацијом из Србије. „Када сам се срео с њима почели су са мном да разговарају љутито и с висине. Не супростављајући им се, замолио сам их да крену за мном. Одвео сам их у Словенско друштво и показао им мале собе. Они су све посматрали са знатижељом и захваљивали ми се. Касније сам им отворио врата великог салона. Чим су се сусрели са призором, јекнуше у знак захвалности за велику услугу коју смо им учинили..." 42

Српска делегација је била више него изненађена што су Бугари сачували све књиге. Чилингиров наводи како су га питали зашто поједине вредне књиге нису узели за попуњавање фондова бугарске народне библиотеке. Његов одговор је био или да их већ поседују, или да су то ипак српско власништво и културно благо.

Већ следећег дана делегација из Србије је дошла са француским комесаром и почели су, уз помоћ библиотекара, не пописујући књиге, да пуне сандуке. Њих је лично печатио француски комесар и печат је понео са собом.

Чилингиров наглашава да је раније српска штампа, али и туђа, говорила о бугарском „варварству", истичући да је чак и Карнеги поклонио 100.000 долара за обнову српске универзитетске, односно народне библиотеке. По предаји књига Србији, уследила је реакција бугарске културне јавности, посебно бугарске емиграције у Енглеској, која је истицала улогу бугарске државе у очувању српских књига.

У наставку овога рада, Чилингиров наводи да је, приликом првих напада Аустријанаца током 1914. године, преместивши своју престоницу из Београда у Ниш, Србија преселила и Универзитетску библиотеку, а када су Бугари заузели нову престоницу, преузете су све мере за пуно очување њених фондова. Посебно истиче да је брига о књигама била таква „да је на крају рата и пре тога Бугарска потрошила неколико хиљада долара за очување српских књига и докумената, и када је француски комесар, надзорник по извршењу Нејског договора, потписао акт... предочио је 35.604 укоричених и 31.425 неукоричених томова, пуно карата и слика и друго, све укупно 152 сандука, од којих су 22 садржала медикаменте и хируршке инструменте". 43

Чилингиров посебно истиче следеће: „Бугарски представник који је предао ове материјале, приметио је, са оправданим поносом, у свом извештају господину Министру просвете, да је овом бригом и враћањем српских књига испуњено једно дело које се може сматрати задивљујућим примером не само бугарске, већ и опште хумане културе. И поред тога што се по одредбама Хашке конвенције забрањује отимање културног богатства као трофеја у рату, сви који данас ратују као и у претходним временима настојали су да обогате своје музеје и библиотеке туђим богатствима. Ово наша држава није учинила са српским књишким благом. Чин који не сме бити непримећен ни данас, а ни касније". ${ }^{44}$

И није остао непримећен, како Чилингиров у истом тону наставља. Наиме, у мировним преговорима у Неју ни на једном заседању није било речи о контрибуцији за оштећена српска културна богатства. Бугарска је била спасена од плаћања десетак милиона лева надокнаде Србији, а лично директор библиотеке био је награђен једним комплетом књига Српске књижевне задруге:

Чилингиров свој текст завршава писмом које је пратило овај комплет, наглашавајући да је „Народна библиотека успела да испуни један међународни споразум и да спасе част и достојанство своје отаџбине". 45

\footnotetext{
42 Исто.

${ }^{43}$ Исто: 67

${ }^{44}$ Исто: 67

${ }^{45}$ Исто: 68
} 
Дирекишору Наровне Библиошеке,

Госӣодину Сйилијану Чилинїирову, Софија.

Поштиовани іосииоgине, По нареgби іосйоgина Јована Томића, Библиошеккара Нароgне библиотее-

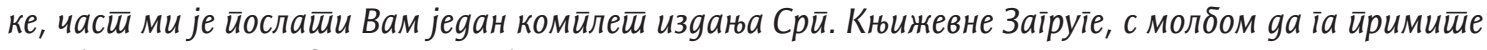
за сећање на њеїово бављење у Софији.

30. маја 1919. ì.

у Софији

С ойличним иоошитовањем

Анасйас Мајзнер

руководилаи, Нароgне библиошеке у Беоїраgу

Потврду о горенаведеним подацима и историчара и самог Чилингирова о примопредаји српских књига можемо пронаћи и у српским изворима. У извештају који Јован Ердељановић, као један од чланова српске делегације, 26. априла 1919. године доставља министру просвете, између осталог стоји:

„Најпре ми је члан комисије, Ст. Чилингиров, директор софијске Народне библиотеке, саопштио, да су све ствари нашег Универзитета, које су из Ниша пренете у Софију, смештене заједно са књигама наше Народне Библиотеке и разних других библиотека из Србије у Софијској Народној библиотеци и у нарочито најмљеној згради преко пута Софијске Народне библиотеке у улици Раковски и да предмета са нашег универзитета нема више нигде у Софији. Зато сам ја најпре прегледао све што има са нашег Универзитета у Софијској народној библиотеци и у поменутој згради. Резултат тога истраживања изнет је у приложеном протоколу, који смо потписали Чилингиров и ја, као чланови, и Нелтнер као председник у завршној седници опште, српско-бугарске комисије.

На моје питање, да ли је од предмета са нашег Универзитета штогод предато софијском универзитету или којој другој установи, Чилингиров ми је одговорио да је он нудио управи софијског универзитета, да прими ствари београдског универзитета на чување, али да је управа ту понуду одбила, а да осталим установама није ништа ни нуђено". ${ }^{46}$

У опширном извештају о посети Народној библиотеци у Софији у циљу преузимања заплењених српских књига који је Јован Томић 29. априла 1919. године доставио министру просвете између осталог стоји:

„У секцији за библиотечке предмете ушли су: директор софијске Народне библиотеке г. Силман Чилингиров и потписани. Ми смо приступили послу већ сутрадан.

С највећом предусретљивошћу г. Чилингиров одвео ме је у зграду преко пута Народне библиотеке, на углу ул. Раковски и ул. Славјанска. У партеру те зграде две одаје испуњене су предметима софијске Народне библиотке, а осталих шест одаја предметима Народне библиотеке у Београду, са београдског Универзитета, јавних и школских библиотека у Нишу, Пироту, Скопљу, Велесу, Кривој Паланци и богословије у Призрену. Књиге и остали предмети нису посебно класификовани ни по библиотекама ни по категоријама, него су измешане и према својим форматима намештене по, за ту зграду нарочито рађеним, полицама. Све су одаје суве, а сем двеју малих остале су довољно осветљене, и у свима је одржана примарна чистота. Услед тога предмети, у колико нису оштећени споља при преносу од Београда до Ниша, при истоваривању, и нарочито при преносу од Ниша до Софије, при незгодним околностима, очувани су добро, тако да ће у реорганизованој нашој Народној библиотеци представљати драгоцен материјал. Само колекција политичких листова због своје велике запремине, није могла бити смештена тамо. Она се налази у сутурену зграде Народне Библиотеке, ул Раковски бр.111, у лошијем локалу, али у сувом и без опасности да се оштети.

${ }_{46}^{46}$ Гаврило Ковијанић, Архивска ірађа о Нароgној библиоешещи у Беоїраяу: 1821-1944, 3. књ. (Београд: Народна библиотека Србије, 1992), 25. 
Сем политичких листова, од којих је Управа Народне Библиотеке у Софији средила каталог, који ми је стављен на расположење, остали библиотечки предмети нису пописивани, без сумње што то захтева врло велики труд и дуго време.

У присуству г. Чилингирова, коме се имам захвалити што су сви библиотечки предмети очувани добро, смештени у сувоту и примерно одржавани - прегледао сам све одаје и у њима смештене предмете. 3бог врло великог броја књига и других библиотечких предмета, преглед се могао ограничити само на стање у каквом се налазе предмети и откуда проистичу, из којих библиотека". ${ }^{47}$

\section{Закључак}

Стилијан Чилингиров, као значајна фигура бугарске културе, својим радом као библиотекар и као историчар расветљава неке недоумице везане за историју појединих српских читалишта, али пре свега за судбину заплењених српских књига у Првом светском рату.

Као интелектуалац у Бугарској почетком 20. века, само тридесетак година после ослобођења земље од Турака, Чилингиров се свесрдно трудио да као књижевник, али и као библиотекар, етнолог, историчар и публициста унапређује нов културни амбијент у својој домовини.

У свом раду, крајње професионално се односио према свим аспектима пословања Народне библиотеке у Софији у коју долази у ратним временима када је најмање пажње обраћано култури. Свестан улоге једне такве националне институције, Чилингиров улаже огромну енергију да је постави на место које заслужује. Као један од високообразованих радника Библиотеке свесрдно се труди да подстакне Министарство народне просвете да заузме став по питању заплењених књига Народне библиотеке Србије и других српских библиотека. Чилингиров приступа послу, показујући и знање и хумани однос према заплењеном српском књижном благу, више пута истичући у својим дописима, записницима и рапортима претпостављенима да очување збирки српских библиотека доживљава као личну мисију и прихвата као часни задатак националне културе и да српске књиге не доживљава као плен и трофеј, те да је обавеза Народне библиотеке у Софији да сачува ово благо од уништења и касније врати власнику. Много енергије и знања Чилингиров улаже у сређивање и смештај такозване „Српске библиотеке", те је са пуно поштовања и поноса као директор софијске Библиотеке 1919. године предаје српској делегацији.

На основу овде изложених података о улози Чилингирова у очувању Народне библиотеке Србије и података до којих је ауторка дошла анализирајући архивски материјал из Бугарског историјског архива при Народној библиотеци у Софији (фонд 35 - историја Народне библиотеке), може да се закључи да се Чилингиров савесно, из перспективе изузетног културног радника, познаваоца књиге и поштоваоца културе суседног народа, у овом случају противника у рату, прихватио посла и, уз изузетно залагање, сачувао и средио српске књиге и после рата их у добром стању предао српској делегацији. 


\title{
Литература и извори:
}

1. Vraneš, Aleksandra. Niška narodna biblioteka: dokument i svakodnevica. Niš: Narodna biblioteka "Stevan Sremac", 2004.

2. БИА, Ф. 35, архивска јединица 593, лист 35.

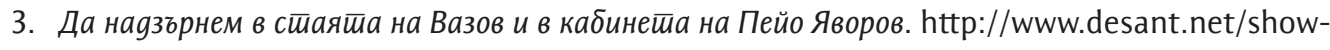
news/37239 (преузето 18. 1. 2017).

4. Dragosavac, Branka. Javne biblioteke u Srbiji od 1901. do 1918. Pančevo: Gradska biblioteka; Niš:Narodna bibliotka "Stevan Sremac”; Negotin: Narodna biblioteka „Dositej Novaković”, 2016.

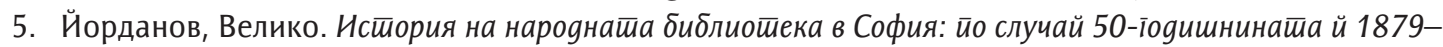
1929. София: Държавна печатница, 1930.

6. Kićović, Miraš. Istorija Narodne biblioteke u Beogradu. Beograd: Narodna biblioteka, 1960.

7. Kovijanić, Gavrilo. Arhivska građa o Narodnoj biblioteci u Beogradu: 1821-1944, 3. knj. Beograd: Narodna biblioteka Srbije, 1992.

8. Леонидов, Румен. Премблианише gневниии на Сйилиян Чилиніиров. https://kibea.net/press/2024 (преузето 12.1. 2017).

9. Мемориален кабинеш̄ Сеиилиян Чилинїиров. http://nlmuseum.bg/index.php/filiali/memorialen-kabinetstiliyan-chilingirov (преузето 13. 1. 2017).

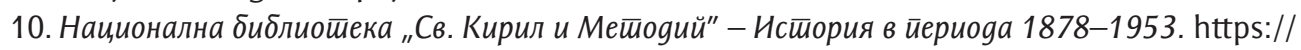
nationallibrary.bg/wp/?page_id=96 (преузето 12. 1. 2017).

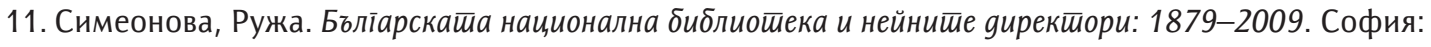
Издателска къща „Христо Ботев”, 2009.

12. Сйилиян Хаgжияобрев Чилиніиров. http://archive.li/cXF8w (преузето 13. 1. 2017).

13. ЦДА Софија, Фонд 108К, опис 2, архивска јединица 2409, Протокол Стилиян Чилингиров.

14. ЦДА София, Фонд 108к, опис 2, Фонд Стилиян Чилингиров.

15. Чилингиров, Стилиян. „Как бяха спасени книгите на Сръбската народна библиотека: (Спомен) ”, Биолиошекар 11 (1958): 64-68.

\section{Stilian Chilingirov and His Contribution to the Preservation of Serbian Libraries Confiscated by the Bulgarians in the First World War}

\author{
Summary \\ Stilian Chilingirov was a prominent cultural figure of Bulgaria in the first half of the $20^{\text {th }}$ century whose work left a \\ significant trace in Bulgarian culture and greatly contributed to the status of Bulgarian social and other libraries. \\ He was engaged in literary and scientific work, theory and history of literature, literary criticism and history. This \\ paper brings little-known information about the role of Stilian Chilingirov in the preservation of the Serbian books \\ seized during the Great War, including the books from the National Library of Serbia. The paper is based on the \\ research done using materials from the Central State Archives, the SS. Cyril and Methodius National Library in Sofia \\ and Chilingirov's memoirs as well as the information presented in a variety of publications related to the history of \\ the Bulgarian National Library. On the basis of the existing historical sources, relatively little is known about the \\ fate of the Serbian books seized in the Great War that were kept in the National Library in Sofia until 1919. The \\ presentation of the previously unknown facts from Bulgarian sources is undoubtedly important for the history of \\ Serbian librarianship.
}

Keywords: Stilian Chilingirov, World War I, book collections from Serbian libraries, pillage, National Library of Serbia, National Library in Sofia (Bulgaria), Jovan Tomić 


\section{Библиотекарят Стилиян Чилингиров и приносът му за опазването на конфискуваните сръбски библиотеки от страна на българите през Първата световна война}

\section{Резюме}

Стилиян Чилингиров е значителен културен деец в България през първата половина на 20 век, който с работата си е оставил значителна следа в българската култура и допринесъл много за статута на българските читалища и библиотеки. Той се занимава с литературна и научна работа, теория и история на литературата, литературна критика и история. Тази статия предоставя досега малко известнни данни ролята на Стилиян Чилингиров в отоапазване на сръбските книги, конфискувани по време на Първата световна война, сред които бяха и книгите от Националната библиотека на Сърбия. Старията е разработена на базата на изследването на архивни материали от Централния държавен архив, Националната библиотека „Св СвКирил и Методий” в София и мемоарите на Чилингиров, както и въз основа на данните представени в различни публикации, свързани с историята на българската национална библиотека. За съдбата на конфискуваните сръбски книги в Първата световна война, за които со 1919 се грижеше Националната библиотека в София, сравнително малко се знае от съществуващите исторически източници, и представянето до сега неизвестни данни от български источници е важно за историята на сръбското библиотекознание.

Ключови думи: Стилиян Чилингиров, Национална библиотека на Сърбия, сръбски книги, Народна библиотека София, Първата световна война, Йован Томич 